\begin{tabular}{|l|l|l||}
\hline \multicolumn{2}{|c|}{ PublisherInfo } \\
\hline \hline PublisherName & $:$ & BioMed Central \\
\hline \hline PublisherLocation & $:$ & London \\
\hline \hline PublisherImprintName & $:$ & BioMed Central \\
\hline \hline
\end{tabular}

\title{
Lab mouse genome isn't simple
}

\begin{tabular}{|l|l|l||}
\hline \multicolumn{2}{|c|}{ ArticleInfo } \\
\hline \hline ArticleID & $:$ & 4967 \\
\hline \hline ArticleDOI & $:$ & $10.1186 /$ gb-spotlight-20040623-01 \\
\hline \hline ArticleCitationID & $:$ & spotlight-20040623-01 \\
\hline \hline ArticleSequenceNumber & $:$ & 30 \\
\hline \hline ArticleCategory & $:$ & Research news \\
\hline ArticleFirstPage & $:$ & 1 \\
\hline \hline ArticleLastPage & $:$ & 3 \\
\hline \hline & & RegistrationDate : 2004-6-23 \\
\hline ArticleHistory & $:$ & OnlineDate \\
\hline \hline ArticleCopyright & $:$ & BioMed Central Ltd2004-6-23 \\
\hline \hline ArticleGrants & $:$ & \\
\hline \hline ArticleContext & $:$ & 130595511 \\
\hline \hline
\end{tabular}


Cathy Holding

Email: cathyholding@aol.com

The patterns of variation between genomes of standard laboratory inbred mice are not as simple as generally believed, according to a team reporting in Proceedings of the National Academy of Sciences USA. The results suggest that researchers will be forced to use other methods in quantitative trait loci (QTL) mapping, as gene identification will become "not impossible, but more challenging," said Richard Mott, who led the study with Jonathan Flint at the Wellcome Trust Centre for Human Genetics, Oxford (Proc Natl Acad Sci USA 2004, 101:9734-9739).

"Inbred strains are great in the sense that they're completely homozygous," said Mott. But laboratory mice were bred originally by amateur scientists who used anything they could catch, said Mott. "They weren't created, generally speaking, for genetic research. The question is, if you look at the genomes of these inbred strains in detail, how do they differ?"

Mott and his team sequenced about $12 \%$ of a 4.8-megabase region known to contain a QTL affecting anxiety in each of eight inbred strains, in pieces distributed fairly uniformly to ensure a good sampling of the region at high resolution. "Essentially, we were sampling every $10 \mathrm{~kb}$," said Mott.

Mott's team investigated whether the same group of strains of inbred mice showed one variant while the other group showed a different variant - the simplest picture of genome variation - based on data from low-level scans of the mouse genomes.

However, instead of a picture of clear haplotype blocks - well defined boundaries showing a shift from one pattern of differences between strains to a different pattern - Mott's team found a structure of haplotype sharing that resembled a mosaic of ancestral trees. Different regions showed a different phylogenetic tree relating the eight strains. "You would see straight distributions which were consistent with the particular family tree linking the eight strains - but that family tree would change as you went along," Mott said.

One of the main conclusions was that "we are going to nee - if not the full sequence of inbred strains we are going to need data at a very high resolution. It won't be enough just to sample steps at every few hundred kb - which is what people are doing at the moment," said Mott.

"It is one of the first papers to take a serious look at detailed sequence comparison across a large number of strains, and I think the results make a great deal of sense," said Mark Daly, research fellow at the Whitehead Institute, "particularly since we have done a very similar study with concordant results." That study is in press, Daly said.

The different conformations of single nucleotide polymorphisms across the eight strains that they looked at show that $99 \%$ of the variation amongst the strains is captured by 13 different patterns, said Daly, who was not involved in the study. "It does in fact offer a very optimistic outlook for how much work will be required in these positional cloning projects in mice," he said.

"I think that this is an important message, and it relies on accurate sequencing and accurate knowledge of the true base pair sequences in the mouse. And I think it's true that that information is not completely accurate yet," said Tamara J. Phillips, professor and vice-chair in the Department of 
Behavioral Neuroscience, Oregon Health and Science University. "How likely it is that we are going to have the resources to go at it the way that they did? That's another question."

"Perhaps the title says it is 'unexpected complexity,' but I think that's in part because there have been some very naïve proposals and naïve interpretations of genetic variation data," said Daly. "I think that more sophisticated readers will not find this complexity necessarily unexpected."

\section{References}

1. Proceedings of the National Academy of Sciences USA, [http://www.pnas.org/]

2. Richard Mott, [http://www.well.ox.ac.uk/rmott/]

3. Mark Daly, [http://www.wi.mit.edu/far/far_daly_bio.html]

4. Tamara J. Phillips, [http://www.ohsu.edu/behneuro/Faculty/TPhillips.html]

This PDF file was created after publication. 